\title{
Crop patterns and habitat preferences of the grey partridge farmland bird
}

\author{
A. JOANNON ${ }^{1 *}$, E. BRO ${ }^{2}$, C. THENAIL ${ }^{1}$, J. BAUDRY $^{1}$ \\ ${ }^{1}$ INRA SAD Paysage, 65 rue de Saint-Brieuc, CS 84215, 35042 Rennes Cedex, France \\ 2 ONCFS, Direction des Études et de la Recherche, Saint-Benoist, BP 20, 78612 Le Perray-en-Yvelines Cedex, France
}

(Accepted 11 February 2008)

\begin{abstract}
Agricultural changes such as intensification and specialization are thought to be the major source of the severe decline of farmland bird populations observed on large spatial scales and over long time spans in Europe. We studied farmers' practices at a local level on 22 farms from the Beauce area, France, with regard to habitat preferences of grey partridge, Perdix perdix L. We focused on the study of vegetation cover because it influences grey partridge's reproduction and survival. The results revealed a high diversity of vegetation cover over the municipal territory. This high diversity can be explained by (1) the difference in the crops cultivated by the farmers, only wheat being cultivated by all the farmers; (2) the diversity of elementary crop sequences implemented, as many as 51 having been identified; and (3) the field size, which varies from 0.5 ha to 57 ha, with $54 \%$ of fields smaller than 10 ha. Altogether, this potentially creates six different habitat types, $32 \%$ of the arable land surveyed being a likely suitable habitat for the grey partridge. We found that irrigation was the main driving factor of vegetation cover diversity. Indeed irrigation controls the farms' crop acreage, the crop sequences and their spatial pattern and field size. Nonetheless, irrigation practices show both positive, e.g. crop diversity, and negative aspects, e.g. large fields and clutch failure, for ground-nesting birds such as the grey partridge. Based on these results, a GIS modeling of the municipal landscape related to grey partridge's habitat requirements is possible and would allow a deeper analysis of the impact of crop diversity on grey partridge populations.
\end{abstract}

cash crop ecosystems / crop sequences / farmland bird biodiversity / grey partridge / technical farm management

\section{INTRODUCTION}

A number of birds and other wildlife species inhabiting farmland have suffered severe declines in Europe, both in range extent and population size, caused by habitat contraction or fragmentation and/or decrease in habitat quality during the last few decades (e.g. Rocamora et al., 1999; Robinson and Sutherland, 2002; BirdLife International, 2004). Historical and geographical datasets support that overall agricultural intensification (increase in chemical inputs and energy per unit of area) and specialization driven by technical progress (chemical input, mechanization, etc.) and policy (e.g. European Common Agricultural Policy, CAP) have been responsible for this decline (e.g. Chamberlain et al., 2000; Benton et al., 2002; Newton, 2004). Mechanisms by which modern farming affects wildlife populations are diverse and are likely to vary among species, including direct mortality, decrease in food abundance, loss of suitable nesting habitat, indirect increase in predation, etc. (e.g. Anderson et al., 2001). These are related to pesticide use (Rands, 1985; Serre and Birkan, 1985),

* Corresponding author: joannon@ rennes.inra.fr changes in crop management, watering practices (Birkan et al., 1990), increase in field size, etc. (Benton et al., 2003; Baudry and Papy, 2001).

Since the loss of farmland biodiversity is attributed to intensive farming practices that have decreased the overall landscape heterogeneity, intensively cultivated farmland is often seen as a homogeneous landscape. This perception can be justified on large spatial scales when compared with other types of landscape, such as "bocage" landscapes highly fragmented by hedgerows. However, on a local scale, open-field landscapes also display heterogeneity due to the crops themselves and their management. This kind of heterogeneity is also important to consider (e.g. Panek, 2002). In these kinds of landscapes farmers create heterogeneity by sowing different crops and by spatiotemporally organizing them over their fields. According to the crops sown, the vegetation height is more or less high, the inter-row width varies, the period with bare soil is more or less long, etc. The crop location in the landscape determines the size of patches with homogenous soil and vegetation states. More widely, the heterogeneity within cropland has an impact on the overall environmental quality of agricultural 


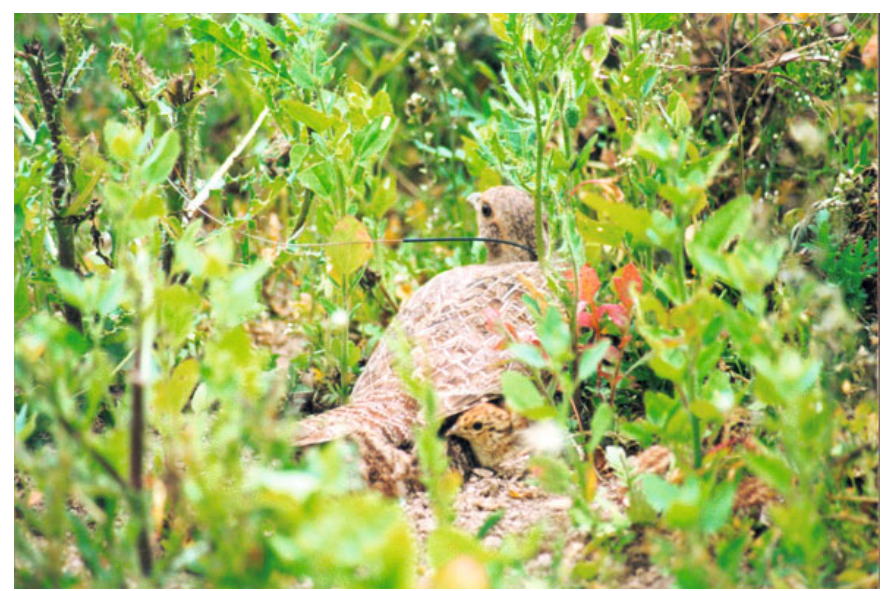

Photo 1. The grey partridge, Perdix perdix L., is a typical farmland species and a culturally important gamebird in Europe. (C)Baudoux B.

landscapes, as shown by Benton et al. (2003) concerning the overall biodiversity; by Joannon et al. (2006) concerning the soil surface runoff on loamy soils; by Beaujouan et al. (2001) concerning the water quality in streams, etc. However, little is known about this kind of heterogeneity and about what drives it. To assess cropland heterogeneity and the diversity of practices driving it, along with the factors explaining this diversity, it is necessary to perform an in-depth analysis at the farm level. Indeed, farmers' practices that can impact cropland heterogeneity are not only dependent on the socio-economic context, but also on the characteristics of the farm's production means, namely the land, machinery and labor force, and their technical management by farmers; that is to say, the way a farmer allocates them to the different units (cash crops, pasture, dairy cows, etc.) of his farm operation (Papy, 2001; Aubry et al., 1998; Thenail and Baudry, 2004). The present study used this level of analysis as a focal point with the primary objective of supporting the design of landscapes that would sustain a greater farmland bird diversity.

To explore this issue the grey partridge, Perdix perdix L., a typical farmland species and a culturally important gamebird in Europe, has been chosen as a case study for four main reasons. (1) It is of particular concern since it has suffered a reduction in range and abundance over recent decades (BirdLife International, 2004; Hagemeijer and Blair, 1997). As a result, the species has become an important management issue. (2) In France, as in other countries in Europe, the overall long-term decline (Bro et al., 2005; Reitz, 2003) has been attributed to habitat modifications through farm specialization and intensification. Habitat modifications in particular have had a negative impact on grey partridge breeding. The choice of nesting sites (first attempt: field margins of small grain cereal crops, to a lesser extent grassy roadsides and hedges; replacement nesting: other crops such as sugar beets or peas: Bro et al., 2000a; Reitz et al., 2002) and causes of clutch failure, among which are machinery and irrigation (Bro et al., 2000b, Birkan et al., 1990) are well documented in France. More broadly, increasing crop diversity in the landscape is likely to increase grey partridge spring density, even if thresholds are not yet well known (Meynier, 2004). (3) Following these results guidelines were proposed, but they have been little applied. The proposed measures aim at dividing large fields of cereals to increase cereal edges that are suitable for nesting sites. This can be achieved through set-aside (for instance, with strips of grass or maize-sorghum mixture) or by spatially alternating crops (in particular, winter cereals and spring crops such as sugar beets, potatoes, etc.). (4) We also chose to study the grey partridge because other bird species, such as the common quail (Coturnix coturnix L.) or the skylark (Alauda arvenis L.), may benefit from research undertaken for the grey partridge since they present some similarities with regard to reproductive ecology (Barbier, 2001; Guyomarc'h, 2003).

Therefore, the aim of this study was firstly to identify which kind of vegetation cover diversity can be found in cultivated fields over the year and across space regarding grey partridge's habitat requirements. Secondly, the objective was also to identify the factors and decision rules at the farm level explaining this diversity over the year, which could help to create more heterogeneous landscapes without changing farms' production strategies or decreasing farmland area or crop yields. We carried out the analyses in the Beauce area in the center of France, an intensive cash crop area representative of the grey partridge's habitat.

\section{MATERIALS AND METHODS}

To address these two questions a farm survey was carried out. We conducted farmer interviews over the farm territory (the whole area managed by the farmer) on crop management practices that could modify the suitability of the landscape for the grey partridge. Crop diversity and field size have been identified as the main factors to consider. For a given crop, the diversity of vegetation cover due to differences in sowing date or irrigation intensity does not significantly change the suitability of the crop for grey partridge nesting and protection needs. Indeed, in the surveyed municipality all the farmers apply relatively intensive management to the crops. That is why our interviews focused on the following practices:

(1) Farm's crop acreage: the diversity of crops cultivated by a farmer is the first factor that influences the crop patchwork over the farm territory: the more numerous the crops are, the more potentially heterogeneous the landscape. We focused on the technical factors that explain the choices of cultivated crops by farmers.

(2) Crop sequences: farmers organize the different crops they cultivate over the years in the fields of the farm, without necessarily designing strict rotations. They rather design flexible crop sequence patterns that they repeat periodically in order to avoid yield reductions due to decreases in soil nutrients, pest infestation, etc. (Magdoff and van Es, 2000; Dogliotti et al., 2003). Crop sequence decision rules were identified from the interviews, not from the analysis of past crop sequences.

(3) Spatial pattern of crop sequences over the farm territory: given the heterogeneity of field characteristics of a farm, crop successions can vary from field to field. Indeed, some fields 
can be more suitable for certain crops, and other fields for other crops, leading farmers to adapt their crop sequences to the field characteristics (Morlon and Benoit, 1990).

(4) Size of cultivated fields: in cash crop areas of France, agricultural land has often been consolidated to create large blocks of land; this part of the interview focused on the reasons why farmers divide these blocks into several fields to which different crops are allocated. From year to year, the division of one block can be different.

Regarding all these points, we interviewed farmers to identify the diversity of their practices and the technical factors of their choices. To analyze farmers' decisions about crop location and crop sequences (points 2 and 3 of the interview) we mobilized a methodology set up by Maxime et al. (1995) that has already been implemented to analyze crop spatial patterning related to natural resource management (Joannon et al., 2006).

Lastly, we characterized crop sequence diversity according to the grey partridge's habitat requirements. We classified them into six classes based on:

- the percentage of small grain cereals in the crop sequences (3 modalities): (1) 50\%; (2) more than 67\%; (3) variable. We postulate that a percentage of $50 \%$ would be a good compromise since having small grain cereals creates habitat for nesting, but having more than $50 \%$ of them would homogenize the landscape, which would decrease the possibilities of protection against predators over the year.

- the number of different crops other than small grain cereals (2 modalities): (1) less than two; (2) three or more. Having more than three crops in the sequence potentially increases the diversity of vegetation cover in fields and so increases the ground cover over the year, especially when small grain cereals are harvested.

We focused on a single municipality in order to have a similar overall environment for all the farms studied in terms of socioeconomic context, recent history of farming systems (shift towards irrigation over the last 30 years), past land consolidation plans (two plans during the last 50 years) and geomorphologic characteristics (north of the Beauce groundwater body). Fresnay-l'Évêque was selected because it has a diversity of soil with regard to soil water storage and stoniness, which we hypothesized to be main constraints of crop location (identified from local data and experts). Poor soils (high stoniness and low soil water storage) are scattered all over the municipality, but different proportions of them have been found in the surveyed farms. Fresnay-l'Évêque is located in the southeastern part of Eure-et-Loir department (longitude 1 ${ }^{\circ} 50^{\prime}$ - latitude $48^{\circ} 16^{\prime}$ ) (Fig. 1). Its area is 2926 ha; $86 \%$ is agricultural land (2516 ha) and the agricultural land is almost only arable land; $80 \%$ is irrigable (SCEES, 2000). Out of a total of 40 farmers, 22 were interviewed. A total of 16 farmers had their farmstead in the municipality and six were outside the municipality. The interviews covered $85 \%$ of the arable land of the municipality and 202 fields (2005 crop pattern), which provided data about farm characteristics and farmers' practices across an almost continuous agricultural landscape.

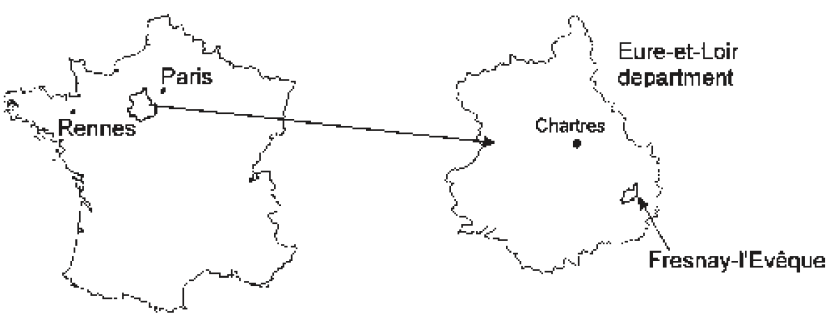

Figure 1. Location of the municipality studied.

\section{RESULTS AND DISCUSSION}

The surveyed farms were very diverse in size, varying from 30 ha to 236 ha. The average farm size was 144 ha. Except for one 30-ha farm, all farms exceeded 100 ha. In all farms at least $70 \%$ of the total arable land was irrigable, and for $55 \%$ of the farms $100 \%$ of arable land was irrigable. This results section first presents the diversity of cultivated crops and of crop sequences at the farm level; then the diversity of the spatial patterns of crop sequences and the design of fields; and lastly, the resulting diversity of the grey partridge habitat.

\subsection{Vegetation cover diversity resulting from crops and crop sequence diversity}

\subsubsection{Farms' crop acreage}

A total of 14 different annual crops was found in the 22 surveyed farms (Tab. I):

- Small grain cereals represented 50 to $70 \%$ of the farm acreage; while winter wheat (Triticum aestivum L.) was cultivated on all farms (25-60\% of the farm acreage), spring wheat was cultivated on $45 \%$ of the farms, spring barley (Hordeum vulgaris L.) on $70 \%$ of the farms and winter barley (Hordeum vulgaris L.) on only one farm.

- Special crops - potatoes (Solanum tuberosum L.), onion (Allium cepa L.), flageolet and green beans (Phaseolus vulgaris L.), green peas (Pisum sativum L. subsp. sativum var. sativum), aromatic crops cultivated on demand for a market gardener (e.g. mint (Mentha verticillata L.), coriander (Coriandrum sativum L.), parsley (Petroselinum sativium L.) etc.), red beet (Beta vulgaris L. subsp. Vulgaris, Conditiva Group) and seed plants), peas (Pisum sativum L. subsp. sativum var. arvense) and corn (Zea mays L.) were present on $80 \%$ of the farms and represented on each farm from $5 \%$ to $30 \%$ of the farm acreage.

- Two crops were cultivated on around $40 \%$ of the farms: sugar beet (Beta vulgaris L. subsp. vulgaris (Altissima Group)) on 5 to $25 \%$ of the crop acreage, and oilseed rape (Brassica napus L.) on 10 to $25 \%$.

There were three main factors mentioned by farmers to explain this diversity of farms' crop acreage:

- The characteristics of fields of the farm territory: soil stoniness, field size and irrigation water availability. These characteristics will be explained in greater detail below. 
Table I. Crop acreage of the 22 surveyed farms.

\begin{tabular}{|c|c|c|c|c|c|c|c|c|}
\hline & \multicolumn{6}{|c|}{ Spring crops } & \multicolumn{2}{|c|}{ Winter crops* } \\
\hline & Special crops & Peas & Corn & Sugar beet & Spring barley & Spring Wheat & Winter Wheat & Oilseed rape \\
\hline Min. Share** & $5 \%$ & $5 \%$ & $5 \%$ & $5 \%$ & $5 \%$ & $5 \%$ & $25 \%$ & $10 \%$ \\
\hline Max. Share** & $30 \%$ & $20 \%$ & $25 \%$ & $25 \%$ & $25 \%$ & $25 \%$ & $60 \%$ & $25 \%$ \\
\hline$\%$ of farms $* * *$ & $80 \%$ & $85 \%$ & $80 \%$ & $40 \%$ & $70 \%$ & $45 \%$ & $100 \%$ & $40 \%$ \\
\hline
\end{tabular}

* Winter barley is not mentioned in the table since it is cultivated on only one farm. It represents $7 \%$ of the crop acreage of that farm.

** For each crop the minimum and maximum shares are those observed among the farms actually cultivating the crop.

*** For each crop it is the percentage of farms actually cultivating the crop among the whole surveyed farms.

- The equipment and labor force available to irrigate crops. Whether a crop is irrigated or not depends on the number of workers on the farm, the flow of the well pump and the number of irrigation devices. On the other hand, crops are more or less water-demanding: spring small grain cereals are the least water-demanding crops, whereas corn and special crops are the highest water-demanding crops. So farmers divide spring acreage between high waterdemanding crops, low water-demanding and non-irrigated crops according to their irrigation capability.

- Quotas and contracts: quotas determined the area of sugar beet, and contracts with food processing companies determined the area of potatoes and other vegetables. Only three farmers among the thirteen farmers cultivating vegetables sold their produce without any contract.

As shown previously by Vavra and Colman (2003), our results show that the profitability of crops is not the only factor that farmers take into account when choosing which crops to cultivate.

Besides crops, arable land is also covered by set-aside, which is a percentage of arable land that farmers must not cultivate with commercial food crops according to the EU Common Agricultural Policy. However, they have to take care of the set-aside land and cannot leave it as bare soil. There were two types of set-aside: grassy set-aside (mainly rye grass (Lolium perenne L.)), either permanent or rotational; and cultivated set-aside, mainly oilseed rape for bio-fuel. Some permanent set-aside was located on small and very stony fields. Another part was used to create pathways between fields or grassy headlands, in order to facilitate the movement of irrigation equipment and to decrease their hindrance to tractor traffic in the irrigated fields. Rotational set-aside was mainly located on headlands of irrigated crops, because these parts of the fields could not be irrigated in a homogeneous way. Moreover, with grassy headlands, farmers more easily avoided wetting the road.

\subsubsection{Crop sequences}

On a farm, farmers organized the crops cultivated in fields over the years. Farmers did not design regular rotations that they repeated over the years, but patterns of crop sequences. These patterns are based on three elementary rules of crop succession. First there are the potential preceding crops, i.e. the crops after which a given crop can be sown. Second, there is a minimum waiting period which corresponds to the number of years between the cultivation of the same crop in the same field. Lastly, these rules determine the maximum number of consecutive years of the same crop in the same field. The rules reported in Table II are the ones given by the farmers during their interviews and do not correspond to agronomic standards. According to the data collected during the interviews, four different types of crops can be defined:

- Type 1: small grain cereals with many potential preceding crops, and a short minimum waiting period; moreover, these crops can be cultivated for several consecutive years on the same field. Among them, wheat is the most cultivated, and the rules applied by the farmers vary: $59 \%$ of the farmers never reseed wheat after wheat on their whole farm or part of it, while $59 \%$ do.

- Type 2: corn, rapeseed oil and aromatic plants with only the small grain cereals as potential preceding crops, with a minimum waiting period similar to type 1 . Farmers do not cultivate these crops for two or more consecutive years.

- Type 3: peas and sugar beet, which are similar to type 2 with the exception of the minimum waiting period, which can be short or long. The variation between farmers is linked to the trade-off between disease risk and potential profit and also to the diversity of other crops that they can cultivate in their fields. $30 \%$ of the farmers cultivating sugar beet apply a short minimum waiting period, and $52 \%$ of the farmers cultivating peas do the same for that crop.

- Type 4: potatoes, onions, beans and other vegetables were also similar to type 2 with the exception of the minimum waiting period. For these crops the period was mostly very long and often written in the contract with the food processing company, if there was one. Only two farmers occasionally repeat potatoes with a minimum waiting period of four years. Since those farmers sell a part of their production on the free market they do not have to comply with food processing company contracts. Moreover, they are both young and have recently invested in specific equipment for potato production, so they try to increase the area of potatoes they cultivate to get a quick return on their investment.

According to these rules, it was possible to define, for the municipality farm set, a general model of elementary crop sequences. The elementary sequences were all made of one breaking crop (the crop starting the sequence and breaking the 
Table II. Basic agronomic rules used by the interviewed farmers to design crop sequences.

\begin{tabular}{|c|c|c|c|c|c|c|}
\hline \multirow{2}{*}{$\begin{array}{l}\text { Crop* } \\
\text { Wheat }\end{array}$} & \multirow{2}{*}{$\begin{array}{c}\text { Potential preceding crop** } \\
\text { All except barley }\end{array}$} & \multicolumn{2}{|c|}{$\begin{array}{l}\text { Minimum waiting period } \\
\text { (years)** }\end{array}$} & \multicolumn{2}{|c|}{$\begin{array}{l}\text { Maximum number of years } \\
\text { at the same location** }\end{array}$} & \multirow{2}{*}{$\begin{array}{c}\text { Type of crop*** } \\
1\end{array}$} \\
\hline & & 2 or & & $\begin{array}{c}1 \\
59 \%\end{array}$ & $\begin{array}{c}\text { more than } 1 \\
59 \%\end{array}$ & \\
\hline Spring barley & All & 2 or & & $\begin{array}{l}1 \text { or } 2 \\
100 \%\end{array}$ & $\begin{array}{c}\text { Single crop } \\
7 \%\end{array}$ & 1 \\
\hline Corn & Wheat / (Barley) & 2 or & & & 1 & 2 \\
\hline Rapeseed oil & Wheat / (Barley) & 2 or & & & 1 & 2 \\
\hline Aromatic plant & Wheat / (Barley) & 2 or & & & 1 & 2 \\
\hline Peas & Wheat / (Barley) & $\begin{array}{l}3 \text { or } 4 \\
52 \%\end{array}$ & $\begin{array}{l}5 \text { to } 7 \\
48 \%\end{array}$ & & 1 & 3 \\
\hline Sugar beet & Wheat / (Barley) & $\begin{array}{l}2 \text { or } 3 \\
30 \%\end{array}$ & $\begin{array}{l}4 \text { to } 6 \\
70 \%\end{array}$ & & 1 & 3 \\
\hline Potatoes & Wheat / (Barley) & $\begin{array}{c}4 \text { occasionally } \\
13 \%\end{array}$ & $\begin{array}{l}5 \text { to } 7 \\
100 \%\end{array}$ & & 1 & 4 \\
\hline Onions & Wheat / (Barley) & 5 to & & & 1 & 4 \\
\hline Beans & Wheat / (Barley) & 5 to & & & 1 & 4 \\
\hline Other vegetable & Wheat / (Barley) & 5 to & & & 1 & 4 \\
\hline
\end{tabular}

* Winter barley is not mentioned because it is farmed by only one farmer. He cultivates that crop as a single crop on reclaimed land.

** For each crop the main modalities of the three agronomic rules are given in the first row. If there are two main different modalities, the percentage of farmers applying each of them is given in a second row. The addition of the two percentages can be over $100 \%$ since a farmer can apply the two modalities on different parts of his farm.

*** The four types of crops or those described in Section 3.1.2.:

Type 1: many potential preceding crops / short minimum waiting period / repetition at the same location.

Type 2: few potential preceding crops / short minimum waiting period / no repetition at the same location.

Type 3: few potential preceding crops / short or long minimum waiting period / no repetition at the same location.

Type 4: few potential preceding crops / long minimum waiting period / no repetition at the same location.

small grain cereal series) followed by 1 to 5 small grain cereals. The possible breaking crops were corn, peas, rapeseed, sugar beet, aromatic plants and vegetables. In a field, elementary sequences were repeated so that minimum waiting periods of crops would be respected. So, an elementary crop sequence is different from a rotation pattern in that it allows more flexibility when repeating it over the years in a field. Two examples are detailed below:

(1) Elementary sequence: Peas -3 or 4 small grain cereals (SGC)

$\rightarrow$ a crop sequence could be: Peas - Wheat (Wh) - Spring barley $(\mathrm{Sb})$ - Sb - Peas - Wh - Wh -Sb

(2) Elementary sequence: Corn or Potatoes or Onions followed by 1 to 3 SGC

$\rightarrow$ a crop sequence could be: Corn - Wh - Onions - Wh - Wh Potatoes - Wh - Sb

\subsection{Vegetation cover diversity resulting from the spatial pattern of crop sequences and fields}

\subsubsection{Spatial pattern of crop sequences}

On a farm, two or three different elementary crop sequences were usually found. They were spatially organized according to three main constraining factors:

- The soil stoniness: in stony fields farmers did not cultivate potatoes and other vegetables; this factor was also constraining, but in a lesser way, for peas (for $37 \%$ of the farmers cultivating peas) and sugar beet (for $67 \%$ of the farmers cultivating sugar beet);

- The irrigation: in non-irrigable fields, farmers did not cultivate potatoes, vegetables, sugar beet or corn. On these fields $55 \%$ of the farmers cultivating peas and farming nonirrigable land did not cultivate that crop on non-irrigable land. When spring barley is grown on irrigable land farmers always irrigate it, but spring barley is also cultivated on non-irrigable land by eight farmers.

- The size of the fields: in small fields (less than three hectares) farmers did not cultivate potatoes and vegetables because of the size of the machines used for harvesting these crops. That was also imposed by the food processing companies which usually harvest the vegetables themselves. Only 4 farmers mentioned that constraint. This does not mean that only they have fields smaller than three hectares, but that other farmers cultivating such small fields either do not cultivate vegetables or harvest the vegetables themselves with their own machines.

An illustration of the on-farm spatial organization of crop sequences is given in Figure 2. Out of all the surveyed farms, 51 different elementary crop sequences were identified, due to the diversity of breaking crops cultivated on farms and to constraints of crop location.

So even if farmers are situated in a cash crop area with fluctuating markets (e.g. contracts for the production of beans appeared 15 years ago and had almost disappeared at the time 


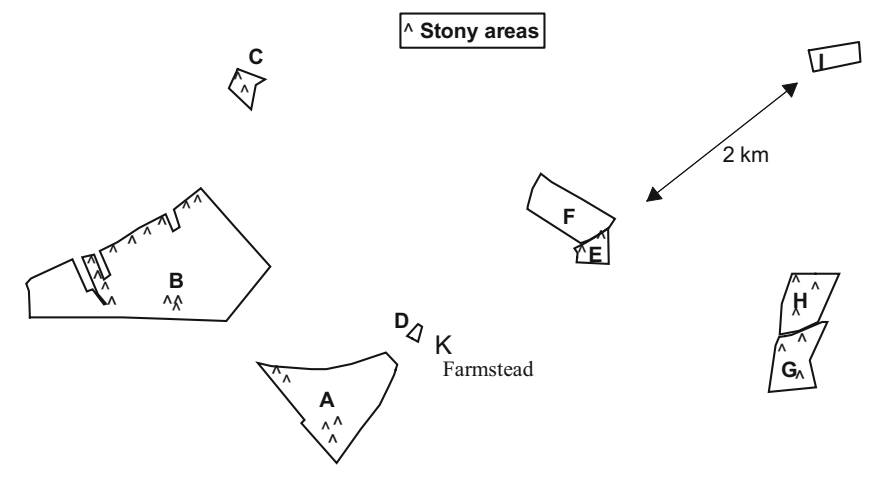

\begin{tabular}{|c|c|c|c|}
\hline Block of land* & Area & Irrigabl & Elementary crop sequence \\
\hline $\mathrm{A}^{* *}$ & 33.5 ha & Yes & \multirow{2}{*}{$\begin{array}{c}\text { Peas or Sugar beet or Corn or Potatoes } \\
\text { Wheat - (Spring barley) / usually } 2 \text { or } 3 \\
\text { different fields in A and } 6 \text { in B / In stony } \\
\text { parts: no potatoes }\end{array}$} \\
\hline $\mathrm{B} * *$ & 86.5 ha & Yes & \\
\hline$\overline{\mathrm{C}}$ & 3.5 ha & No & Permanent set-aside \\
\hline$\overline{\mathrm{D}}$ & 0.5 ha & No & \multirow{3}{*}{$\begin{array}{l}\text {-Peas - Wheat - Wheat or Spring barley } \\
\text { - Spring barley }\end{array}$} \\
\hline$\overline{\mathrm{E}}$ & $4.5 \mathrm{ha}$ & No & \\
\hline$\overline{\mathrm{F}}$ & $12.5 \mathrm{ha}$ & No & \\
\hline $\mathrm{G}^{* * *}$ & 9 ha & No & \multirow{2}{*}{$\begin{array}{c}\text { Winter barley as a single crop and } \\
\text { permanent set-aside }\end{array}$} \\
\hline$\overline{\mathrm{H}^{* * * *}}$ & $11.5 \mathrm{ha}$ & No & \\
\hline$\overline{\mathrm{I}}$ & 9.5 ha & No & $\begin{array}{c}\text { Peas - Wheat - Wheat or Spring barley - } \\
\text { Spring barley }\end{array}$ \\
\hline
\end{tabular}

* All the blocks of land are within a distance of $2 \mathrm{~km}$ from the farmstead, except the "I".

** Those two blocks are divided each year into several fields sown with different crops.

*** These fields are located on reclaimed land.

Figure 2. Spatial patterns of crop sequences and set-asides on a farm in Fresnay-l'Évêque, Beauce.

of the survey), general decision rules for crop location at the farm level exist. If farmers do not implement regular crop rotation over the years, the crop sequences they build are based on agronomic rules that result in regularity of the crop sequences, and we could identify a model of elementary crop sequences. Our results confirm those of Joannon et al. (2006) and Bellon and Doré (2005). The fact that farmers do not implement regular crop rotations also explains why a large number of crop sequences can be found over a large area when farmers can cultivate a great diversity of crops. That is the case in the study of Leteinturier et al. (2006), in which 62499 different sevenyear crop sequences were found over 255461 ha. But we have shown in our study that that does not signify that farmers have no rules for building crop sequences.

\subsubsection{Size of cultivated fields}

The diversity of vegetation cover in a given block of land cultivated by one farmer was also influenced by the size of cultivated fields. The cultivated field size ranged from 0.5 ha to 57 ha. Table IIIa gives the distribution of the fields broken into 4 classes. While fields bigger than 10 ha represent less than half of the sample, they cover $74 \%$ of the area. However, the size of the fields is quite diverse since $17 \%$ of the cultivated fields in the surveyed farms are small (less than 3 ha). Having this kind of small field in the landscape gives the opportunity to create vegetation cover diversity in between the large fields.

In the interviews, three factors that influence the size of cultivated fields were identified:

- The type of crop: the size of wheat fields was much larger than other crop fields, total cultivated wheat acreage on farms often exceeding 45 ha; conversely, the acreage of special crops on farms, and often of other breaking crops, was generally small, representing between 5 and 25 ha on farms. So, when cultivating these last crops in blocks of 40 ha to 100 ha, farmers had to divide them into several smaller fields. Table IIIb shows that wheat fields are larger than all other fields. This was confirmed by the analysis of variance performed with Systat9 (Fig. 3). The hypothesis that the size of the fields is equal regardless of land use is rejected at a level of significance of $P=0.026$.

- Irrigation equipment: the mobility and size of the irrigation equipment influenced farmers' design of fields. Two types of equipment were found. The first was the center-pivot or the linear-move system, depending if the system turned or not. In the municipality there were six move systems on four farms, from 250 meters to 500 meters in width. Since such equipment is difficult to move, farmers designed large fields of the same crop to be irrigated. The other equipment, an overhead sprinkler, is smaller and easier to move, with an irrigation width of 72 meters. With such equipment farmers could more easily irrigate small fields, even smaller than three hectares.

- Water drifting: depending on the wind, the edge of a field could be less irrigated or water could drift onto a nearby field. Consequently, farmers tried not to scatter the same irrigated crop over several fields and also tried to locate different irrigated crops in adjacent fields to minimize water drift.

This survey points out the fact that field size was not directly related to tractor traffic and tillage in fields, but much more to irrigation. Most of the interviewed farmers stated that dividing a big field into several 10- or 15-ha fields would not result in a loss of time when plowing, tilling and sowing it. Our results agree with the study of Francart and Pivot (1998), which had shown that increasing field size over five hectares did not significantly decrease the time spent working in the fields.

\subsection{Grey partridge's habitat diversity}

The classification of the 51 elementary crop sequences in regard to the grey partridge's habitat requirements as explained in the materials and method section is reported in Table IV. The sub-blocks are the blocks broken down by elementary crop sequences. So a sub-block is farmed by only one farmer and only one elementary crop sequence is applied on it, but it can be divided into several fields. Among the six classes 
Table III. (a) Distribution of the fields by size. (b) Size of the fields by land use.

\begin{tabular}{lcccc} 
(a) & \multicolumn{5}{l}{} \\
\hline Field area & Number of fields & $\%$ of total fields & Area of fields (ha) & $\%$ of total area \\
\hline Less than 3 ha & 34 & $17 \%$ & 61 & $3 \%$ \\
3 to 10 ha & 78 & $39 \%$ & 493 & $23 \%$ \\
10 to 20 ha & 46 & $30 \%$ & 789 & $37 \%$ \\
More than 20 ha & 30 & $15 \%$ & 793 & $37 \%$ \\
\hline
\end{tabular}

\begin{tabular}{lcccccccc} 
(b) & Wheat & Sugar Beet & Oilseed rape & Corn & Spring Barley & Peas & Vegetables & All \\
\hline Land Use & 14.3 & 8.9 & 10.8 & 8.6 & 9.0 & 9.9 & 9.7 & 11.2 \\
\hline Mean size & 67 & 10 & 8 & 29 & 18 & 23 & 22 & 177 \\
Number of fields & 0.5 & 5 & 2.2 & 2 & 2.3 & 0.5 & 1.25 & 0.5 \\
Minimum size & 57 & 15.8 & 24 & 36 & 19 & 28 & 25 & 57 \\
Maximum size & 57 &
\end{tabular}

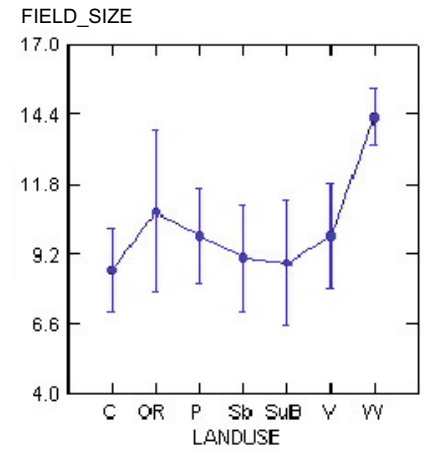

C: corn / OR: oilseed rape / P: peas / Sb: spring barley / SuB: sugar beet / V: vegetables / W: wheat.

Figure 3. Analysis of variance of the size of fields according to land use.

resulting from the two indicators (crop diversity and percentage of small grain cereals in the elementary crop sequences), Class 21 is likely to be the most suitable for the grey partridge. It corresponds to elementary crop sequences with a high diversity of crops and $50 \%$ of small grain cereals. This class represents $32 \%$ of the surveyed arable area. The elementary crop sequences of Class 23, which is also characterized by a high diversity of crops but with a variable percentage of small grain cereals, is also potentially quite suitable for the grey partridge. This class represents $34 \%$ of the surveyed arable area. Together, classes 21 and 23 cover $66 \%$ of the land surveyed. They both correspond to elementary crop sequences including at least four different crops. The limit of this indicator is that it is only based on the elementary crop sequences: it is basically an indicator of the temporal diversity of vegetation cover, while the key component of grey partridge's habitat quality is the spatial diversity of vegetation cover. However, a temporal diversity of crops is likely to lead to a spatial diversity since farmers cultivate each crop of the sequence every year and rotate them over the years. Our results complement those of other studies carried out on broader scales. As stated in the introduction, regional studies have pointed out the impacts of intensification of agriculture on farmland bird biodi-
Table IV. Elementary crop sequence diversity in regards to grey partridge's habitat requirement.

\begin{tabular}{lccccccc}
\hline Class of sequence & 11 & 12 & 13 & 21 & 22 & 23 & All \\
\hline Total area (ha) & 106 & 283 & 146 & 698 & 207 & 754 & 2.193 \\
Total area (\%) & $5 \%$ & $13 \%$ & $7 \%$ & $32 \%$ & $9 \%$ & $34 \%$ & $100 \%$ \\
Number of sub-blocks & 19 & 22 & 12 & 18 & 3 & 17 & 91 \\
Mean area of the sub-blocks & 6 & 13 & 12 & 39 & 69 & 44 & 24 \\
\hline
\end{tabular}

Class 1x: elementary crop sequences with 0 to 2 crops other than small grain cereals.

Class $2 x$ : elementary crop sequences with at least 3 crops other than small grain cereals.

Class $\mathrm{x} 1$ : elementary crop sequences with $50 \%$ of small grain cereals.

Class x2: elementary crop sequences with more than $67 \%$ of small grain cereals.

Class $\mathrm{x} 3$ : elementary crop sequences with at least $50 \%$ of small grain cereals (variable percentage).

versity. Local studies like ours show that within a supposed 'regionally homogeneous' intensive agriculture, a certain diversity of practices exists locally among farmers that could also affect farmland bird biodiversity. This diversity of practices leads to landscape heterogeneity as shown in Figure 4, diversity that may partially explain the spatiotemporal variability in grey partridge abundance and reproductive success (Bro et al., 2005).

The analysis of the technical constraints that determine farmers' crop acreage, crop location and field size (and thus the potential heterogeneity of the landscape) reveals that in the irrigated part of the Beauce, irrigation is a main factor driving the spatial organization of arable land. This factor is more important than the loss of time when working with tractors and machinery in fields. But the effects of irrigation were clearly outlined as contradictory. On the one hand, crop mosaic heterogeneity can be increased (increase in the diversity of crops and of crop sequences) and on the other hand, it can be decreased since irrigation is a main factor for designing large fields. In addition, irrigation has been shown to have an important adverse impact on partridge reproductive success (Birkan et al., 1990; Bro et al., 2000b). This illustrates the fact that the impact of agriculture on wildlife populations and more broadly 

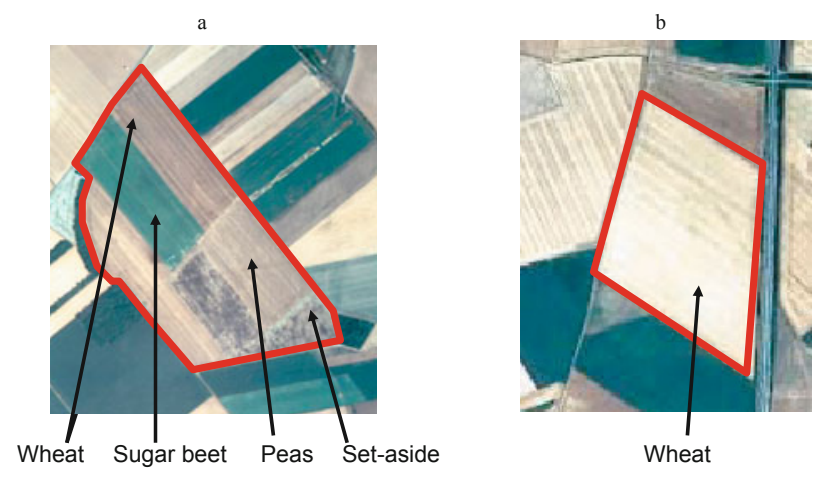

a: Block of land of 50 ha cultivated by a farmer who divides it into five fields of 10 ha each.

b: Block of land of 30 ha cultivated by another farmer, who either divides it into 2 fields or sows the whole block of land with a small grain cereal as shown in the figure

Figure 4. Landscape heterogeneity in two blocks of land cultivated by two different farmers (aerial picture taken in August 2002).

Copyright IGN, Paris, 2002.

on biodiversity is not simply negative or positive, even in a context of intensive agriculture.

\section{CONCLUSION}

Our results show that in an intensive cash crop area, usually considered as having a low diversity of vegetation covers on a large scale, diversity exists locally and creates different types of local landscapes more or less suitable for the grey partridge. Indeed, in the municipality studied, due to the diversity of crops cultivated by farmers and the diversity of farm territory characteristics, 51 elementary crop sequences are implemented by the 22 farmers interviewed. These elementary crop sequences potentially create six types of local landscapes, one of them being the most suitable for the grey partridge. Moreover, the diversity of vegetation covers is created by the field patterns. While large fields over 10 ha cover $74 \%$ of the land surveyed, smaller fields are still numerous (56\% of the fields surveyed). This landscape heterogeneity in cash crop areas was not foreseen in previous grey partridge studies. Our study also shows that the main factors of vegetation cover diversity identified were the irrigation capability on the farm (irrigation equipment, water pump flow and labor availability); the proportion of the different types of soil of the area, especially the percentage of stony fields; and local markets allowing crop diversification. Irrigation has been clearly identified as a factor having contradictory effects on landscape heterogeneity. Based on our results showing a diversity of crops and crop sequences regarding the grey partridge's habitat requirements and following Meyer et al.'s (in press) methodology, it is possible to build a map of the municipality indicating the favorable areas for nesting and raising grey partridge chicks. The next step will be to set up a spatially explicit monitoring of grey partridge populations (breeding density and reproductive success) in order to validate our hypothesis about grey partridge's habitat and landscape heterogeneity in cash crop landscapes with few permanent elements.

\section{REFERENCES}

Anderson C.Q.A., Bradbury R.B., Evans A.D. (2001) Evidence for the effects of agricultural intensification on wild bird in the UK, RSPB Research report No. 3, Sandy, UK, Royal Society for the Protection of Birds.

Aubry C., Papy F., Capillon A. (1998) Modelling decision-making processes for annual crop management, Agr. Syst. 56, 45-65.

Barbier L. (2001) Elements for a skylark (Alauda arvensis) management plan, Game Wildlife Sci. 18, 45-83.

Baudry J., Papy F. (2001) The role of landscape heterogeneity, in: the sustainability of cropping systems, in: Nösberger J., Geiger H.H., Struik P.C. (Eds.), Crop Science - Progress and Prospects, CABI Publishing, Oxon, pp. 243-259.

Beaujouan V., Durand P., Ruiz L. (2001) Modelling the effect of the spatial distribution of agricultural practices on nitrogen fluxes in rural catchments, Ecol. Model. 137, 93-105.

Bellon S., Doré T. (2005) Stability or fluctuations of crop sequences? in: Jacobsen S.E., Jensen C.R., Porter J.R. (Eds.), Proceedings of the VIII Congress of the European Society for Agronomy, 11-15 July 2004, Copenhagen, Denmark, 3 p.

Benton T.G., Bryant D.M., Cole L., Crick H.Q.P. (2002) Linking agricultural practice to insect and bird populations: a historical study over three decades, J. Appl. Ecol. 39, 673-687.

Benton T.G., Vickery J.A., Wilson J.D. (2003) Farmland biodiversity: is habitat heterogeneity the key? Trends Ecol. Evol. 18, 182-188.

BirdLife International (2004) Birds in Europe: population estimates, trends and conservation status. - BirdLife International, BirdLife Conservation Series No. 12, UK.

Birkan M., Serre D., Pelard E., Skibnienski S. (1990) Effects of irrigation on adult mortality and reproduction of gray partridge in a wheat farming system, in: Church K.E., Warner R.E., Brady Perdix S.J. (Eds.), Gray partridge and ring-necked pheasant workshop, Kansas Department of Wildlife and Parks, Emporia, KS, USA, pp. 257271.

Bro E., Reitz F., Clobert J., Mayot P. (2000a) Nest-site selection of grey partridge (Perdix perdix) on agricultural lands in north-central France, Game Wildlife Sci. 17, 1-16.

Bro E., Reitz F., Clobert J., Mayot P. (2000b) Nesting success of grey partridges (Perdix perdix) on agricultural land in North-Central France, relation to nesting cover and predator abundance, Game Wildlife Sci. 17, 199-218.

Bro E., Reitz F., Landry P. (2005) Grey partridge population status in central northern France: spatial variability in density and 1994-2004 trend, Wildlife Biol. 11, 287-298.

Chamberlain D.E., Fuller R.J., Bunce R.G.H., Duckworth J.C., Shrubb M. (2000) Changes in the abundance of farmland birds in relation to the timing of agricultural intensification in England and Wales, J. Appl. Ecol. 37, 771-788.

Dogliotti S., Rossing W.A.H., Van Ittersum M.K. (2003) ROTAT, a tool for systematically generating crop rotations, Eur. J. Agron. 19, 239250.

Francart C., Pivot J.M. (1998) Incidences de la structure du parcellaire sur le fonctionnement des exploitations agricoles en régions de bocage, Ingénieries EAT 14, 41-54.

Guyomarc'h J.C. (2003) Elements for a common quail (Coturnix c. coturnix) management plan, Game Wildlife Sci. 20, 1-92.

Hagemeijer W.J.M., Blair M.J. (1997) (Eds.) The EBCC atlas of European Breeding Birds, Their distribution and abundance, Poyser, Great Britain. 
Joannon A., Souchère V., Papy F., Martin P. (2006) Reducing runoff by managing crop location at the catchment level: considering agronomic constraints at farm level, Land Degrad. Dev. 17, 467-478.

Leteinturier B., Herman J.L., de Longueville F., Quintin L., Oger R. (2006) Adaptation of a crop sequence indicator based on a land parcel management system, Agr. Ecosyst. Environ. 112, 324-334.

Magdoff F.R., van Es H.M. (2000) (Eds.) Building Soils for Better Crops, Handbook Series Book 4. Sustainable Agric. Network, Beltsville, MD, USA.

Maxime F., Mollet J.M., Papy F. (1995) Aide au raisonnement de l'assolement en grande culture, Cahiers Agric. 4, 351-362.

Meynier F. (2004) Analyse des relations entre les densités de perdrix grises et les caractéristiques de l'habitat en plaine de grande culture à trois échelles spatiales, Mémoire de Diplôme d'Études Approfondies, Université Pierre et Marie Curie.

Meyer B.C., Mammen K., Grabaum R. (in press) A spatially explicit model for integrating species assessment into landscape planning as exemplified by the Corn Bunting (Emberiza calandra), J. Nature Conserv. doi:10.1016/j.jnc.2007.01.001.

Morlon P., Benoit M. (1990) Étude méthodologique d'un parcellaire d'exploitation agricole en tant que système, Agronomie 6, 499-508.

Newton I. (2004) The recent decline of farmland bird populations in Britain: an appraisal of causal factors and conservation actions, Ibis 146, 579-600.

Panek M. (2002) Space use, nesting sites and breeding success of grey partridge (Perdix perdix) in two agricultural management systems in western Poland, Game Wildlife Sci. 19, 313-326.

Papy F. (2001) Interdépendance des systèmes de culture dans l'exploitation, in: Malézieux E., Trébuil G., Jaegger M. (Eds.),
Modélisation des agroécosystèmes et aide à la décision, INRA Éditions/CIRAD, Coll. Repères, France, pp. 51-74.

Rands M.R.W. (1985) Pesticide use on cereals and the survival of grey partridge chicks: a field experiment, J. Appl. Ecol. 22, 49-54.

Reitz F. (2003) Le statut communal de la perdrix grise et de la perdrix rouge en France : résultats d'une enquête, Faune Sauvage 258, 2533.

Reitz F., le Goff E., Fuzeau M. (2002) Landscape selection by grey partridge (Perdix perdix) for nesting in the fields of french cereal agrosystems, Game Wildlife Sci. 19, 209-220.

Robinson R.A., Sutherland W.J. (2002) Post-war changes in arable farming and biodiversity in Great Britain, J. Appl. Ecol. 39, 157-176.

Rocamora G., Yeatman-Berthelot D. (1999) Oiseaux menacés et à surveiller en France, Liste rouge et priorité, Populations, tendances, menaces et conservation, SEOF/LPO, France, 598 p.

Serre D., Birkan M. (1985) Incidence des traitements insecticides sur les ressources alimentaires des poussins de la perdrix grise (Perdix Perdix L.) dans un agrosystème de Beauce, Gibier Faune Sauvage 4, 21-61.

SCEES (Service central des enquêtes et études statistiques du Ministère de l'agriculture et de la pêche) (2000) Recensement général agricole.

Thenail C., Baudry J. (2004) Variation of farm spatial land use pattern according to the structure of hedgerow network (bocage) landscape: a case study in northeast Brittany, Agr. Ecosyst. Environ. 101, 5372 .

Vavra P., Colman D. (2003) The analysis of UK crop allocation at the farm level: implications for supply response analysis, Agr. Syst. 76, 697-713. 